\title{
Thyroid hormone metabolism and environmental chemical exposure
}

Marike M Leijs ${ }^{1,2,3+}$, Gavin W ten Tusscher ${ }^{4+}$, Kees Olie', Tom van Teunenbroek ${ }^{6}$, Wim MC van Aalderen ${ }^{1}$, Pim de Voogt ${ }^{2,5}$, Tom Vulsma ${ }^{1}$, Alena Bartonova ${ }^{7}$, Martin Krayer von Krauss ${ }^{8}$, Claudia Mosoiu ${ }^{9}$, Horacio Riojas-Rodriguez ${ }^{10}$, Gemma Calamandrei ${ }^{11}$, Janna G Koppe ${ }^{12^{*}}$

From HENVINET (Health and Environment Network) final conference Brussels, Belgium. 14 April 2010 - 15 April 2010

\begin{abstract}
Background: Polychlorinated dioxins and -furans (PCDD/Fs) and polychlorinated-biphenyls (PCBs) are environmental toxicants that have been proven to influence thyroid metabolism both in animal studies and in human beings. In recent years polybrominated diphenyl ethers (PBDEs) also have been found to have a negative influence on thyroid hormone metabolism. The lower brominated flame retardants are now banned in the EU, however higher brominated decabromo-diphenyl ether (DBDE) and the brominated flame retardant hexabromocyclododecane (HBCD) are not yet banned. They too can negatively influence thyroid hormone metabolism. An additional brominated flame retardant that is still in use is tetrabromobisphenol-A (TBBPA), which has also been shown to influence thyroid hormone metabolism.

Influences of brominated flame retardants, PCDD/F's and dioxin like-PCBs (dl-PCB's) on thyroid hormone metabolism in adolescence in the Netherlands will be presented in this study and determined if there are reasons for concern to human health for these toxins. In the period 1987-1991, a cohort of mother-baby pairs was formed in order to detect abnormalities in relation to dioxin levels in the perinatal period. The study demonstrated that PCDD/Fs were found around the time of birth, suggesting a modulation of the setpoint of thyroid hormone metabolism with a higher 3,3', 5,5'tetrathyroxine (T4) levels and an increased thyroid stimulating hormone (TSH). While the same serum thyroid hormone tests (- TSH and T4) were again normal by 2 years of age and were still normal at 8-12 years, adolescence is a period with extra stress on thyroid hormone metabolism. Therefore we measured serum levels of TSH, T4, 3,3,5triiodothyronine (T3), free T4 (FT4), antibodies and thyroxine-binding globulin (TBG) in our adolescent cohort.

Methods: Vena puncture was performed to obtain samples for the measurement of thyroid hormone metabolism related parameters and the current serum dioxin (PCDD/Fs), PCB and PBDE levels.

Results: The current levels of T3 were positively correlated to BDE-99. A positive trend with FT4 and BDE-99 was also seen, while a positive correlation with T3 and dl-PCB was also seen. No correlation with TBG was seen for any of the contaminants. Neither the prenatal nor the current PCDD/F levels showed a relationship with the thyroid parameters in this relatively small group.

Conclusion: Once again the thyroid hormone metabolism (an increase in T3) seems to have been influenced by current background levels of common environmental contaminants: dl-PCBs and BDE-99. T3 is a product of target organs and abnormalities might indicate effects on hormone transporters and could cause pathology. While the influence on T3 levels may have been compensated, because the adolescents functioned normal at the time of the study period, it is questionable if this compensation is enough for all organs depending on thyroid hormones.
\end{abstract}

\footnotetext{
* Correspondence: janna.koppe@inter.nl.net

+ Contributed equally

${ }^{12}$ Ecobaby Foundation, Hollandstraat 6, 3634 AT Loenersloot, The Netherlands

Full list of author information is available at the end of the article
} 


\section{Background}

Polychlorinated biphenyls (PCBs) and dioxins (PCDDs/Fs), especially TCDD (2,3,7,8-tetrachloro-dibenzo-p-dioxin) are well known developmental endocrine disruptors. PCDDs/Fs and planar (dioxin-like, dl-) PCBs are often grouped together as 'dioxins' or 'dioxin-like compounds', because of their common mode of (toxic) action, via the Ah-receptor.

PCDDs and PCDFs are unwanted by-products of the production of chlorinated phenols, metallurgic processes, bleaching of paper pulp and the incineration of waste [1-3]. PCBs have been produced world-wide from the 1930s and were mainly used as dielectric fluids in electrical transformers and capacitors, as heat exchange or hydraulic fluids [4].

The polybrominated diphenylethers (PBDEs) have been widely used over the last few decades as flame retardants in various materials such as electronic equipment, plastics, foams (e.g. used in car seats and furniture), carpet liners and textiles. Humans are exposed to PBDEs mainly by ingestion (from food and milk) and by inhalation of indoor air and dust. Currently, these compounds are frequently detected in humans all over the world $[5,6]$. The penta- and octa brominated diphenylethers are banned in the European Union, but are still present in the environment. Furthermore, three others, also blamed for interfering with thyroid hormone metabolism are still in use, decabromo diphenyl ether (DBDE), hexabromocyclododecane (HBCD), and tetrabromobisphenol A (TBBPA). The first two were extensively addressed in the HENVINET project. This FP6 EU HENVINET project aimed at synthesizing scientific information available on a number of topics of high relevance to researchers and policy makers in the field of environment and health (E.C. grant: HENVINET 037019). The third one TBBPA is currently found in human beings and can traverse the placenta as it has been found in babies born by caesarean section in hospitals. [7] TBBPA has a half life of 2 days and is excreted as a glucuronide or a sulphate in the faeces via the bile. In animal studies effects are detected on the apical part of the cochlea and an increase in pituitary weight was observed $[8,9]$. The specific thyroid hormone nuclear receptor TR- 32 , only present in the cochlea, pituitary gland and hypothalamus might play a role. Considering the findings in babies born in hospital the margin of exposure is very low and current use of TBBPA is therefore a matter of concern for human health, especially in the perinatal period. Thyroid hormone is essential for normal body metabolism, growth, and development including reproduction, maturation and ageing. Fluctuations in thyroid hormone levels are able to alter outcomes in children [10,11].
Large amounts of these compounds have been released into the environment through the processes previously stated. Organisms, and ultimately humans, are exposed via ingestion (food, drinking water), via inhalation, and via dermal contact. Ingestion is the main source $(90 \%)$ of exposure, primarily through meat and meat products (23$27 \%)$, dairy products (17-27\%) and fish (16-26\%) [12]. Due to the accumulating properties of these compounds, each step higher in the food chain increases the concentration of dioxins in an organism (bioaccumulation). Once ingested, dioxins and PCBs are primarily stored in the liver followed by the adipose tissue. After ingestion dioxins and PCBs are detectable for a long period. The mean halflife of dioxins and PCBs in the human body is assumed to be 7 to 9 years [13].

Dioxins, PCBs and PBDE's are also able to cross the placenta[14] . In addition, they are excreted in breast milk and thereby cause significant exposure to nursing offspring [15]. Adolescents, undergoing hormonal changes during puberty, are probably also at greater risk of susceptibility, and therefore at higher risk, with regards to environmental exposure health effects [16].

Background concentrations, concentrations that average individuals in Europe and the US are daily exposed to, have been related to various negative health effects. Studies have shown negative effects on lung function $[17,18]$, and haematological and immunological disturbances [19-21]. In addition, an increase in behavioural problems was seen, and prolonged evoked responses measured with EEG (electro-encephalography) and MEG (magneto-encephalography), and possible indications of subtle neurological abnormalities were found in children [22-25].

Previous studies of the current cohort showed a higher T4/TBG ratio that became significantly higher at 7 days and 11 weeks after birth, together with an increase in TSH. This finding was interpreted as an hypothyroidal state of the hypothalamic cells involved in thyroid hormone metabolism caused by dioxins [26].

In this study thyroid hormone parameters were investigated in relation to prenatal and early postnatal PCDD/F exposure and current exposure of $\mathrm{PCDD} / \mathrm{F}$ and $\mathrm{dl}-\mathrm{PCBs}$ and the lower brominated PBDE's during adolescence.

\section{Methods \\ Study population}

This study is part of a longitudinal cohort study of 14-19 year old children, studied during their neonatal $(n=60)$, [27] toddler $(n=60)$ [28] and pre-pubertal period $(n=41)$ [22]. All 33 children (18 girls and 15 boys) participating in the current follow-up were born in the Amsterdam/ Zaandam region. Twenty-five of the children are still inhabitants of the region. PCDD/F exposure was determined in the perinatal period in breast milk. Of the total cohort of 
41 subjects who participated in the pre-pubertal study, one subject was excluded from the current follow-up because of a Ewing sarcoma and one was partly excluded because of an extra Y-chromosome (XYY). Five subjects declined to participate in the new follow-up, three could not be traced. One of the children, who did not participate in the pre-pubertal follow-up, consented to the current follow up. Of the 33 examined adolescents 2 refused to undergo vena puncture and 2 refused a repeated puncture after blood clotting in the first needle.

The study was approved by the institutional medical ethics committee. All participants of the study and their parents signed an informed consent.

\section{Laboratory analyses}

Perinatal PCDD/F levels and current serum levels of $\mathrm{PCDD} / \mathrm{Fs}, \mathrm{dl}-\mathrm{PCBs}$ and PBDEs were measured in an uncontaminated laboratory dedicated to low-level dioxin sample treatment, at the Environmental Chemistry Section of IBED/ESS of the University of Amsterdam. Concentrations of the 19 most toxic PCDD/F congeners (seven PCDDs and twelve PCDFs) and the concentration of $3 \mathrm{dl}-$ PCBs $(77,126,169)$ and 8 PBDEs $(28,47,85,99,100,153$, 154 and 183) were determined. The concentration of $\mathrm{PCDD} / \mathrm{F}$ and $\mathrm{dl}-\mathrm{PCB}$ congeners are expressed in toxic equivalents (TEQ) $\mathrm{ng} / \mathrm{kg}=\mathrm{pg} / \mathrm{g}$ fat .

An activated carbon column (Carbosphere) was used for group separation of the chemicals. The PCDD/F and dl-PCB fraction was isolated and a clean-up was performed using a column of AgNO3 on silica gel and a column of activated $\mathrm{Al} 2 \mathrm{O} 3$ on silica gel. The PBDE fraction was purified using activated $\mathrm{Al} 2 \mathrm{O} 3$ on silica gel and an activated alumina column. After concentrating the sample, quantification of dioxins and dl-PCBs was done using hr-GC/hr-MS. PBDEs were determined by hr-GC/ lr-MS. As an internal standard, a mixture of 13C-labelled PCDD/Fs, dl-PCBs and PBDEs was used. More detailed information about the analysis have been published elsewhere [6].

$\mathrm{PCDD} / \mathrm{F}$ concentrations were previously determined in the mothers' milk 3-4 weeks after birth, which is indicative of the prenatal exposure. The cumulative total postnatal/ lactational exposure was calculated as the measured
PCDD/F concentration in breast milk multiplied by the total breast milk intake. [29] Results see table 1.

\section{Statistical analyses}

For statistical analyses the non-parametric Spearman's correlation coefficient was calculated using SPSS- 14.0. The level of significance was $5 \%(\mathrm{P}=0.05)$ for the analysis with the predicted variables. For the congener specific analysis the level of significance was $5 / 8 \%(\mathrm{P}=0.0063)$, to correct for the number of analyses.

As outcome variables we used serum T3, T4, FT4, TSH and TBG. The prenatal, lactational and current serum $\mathrm{PCDD} / \mathrm{Fs}$ and the current serum dl-PCBs and $\Sigma$ PBDE levels were the predicted variables using the Spearman's correlation coefficient. A congener specific analysis of the PBDEs was performed.

\section{Results \\ PCDDs/Fs}

No correlations were found between prenatal dioxin exposure and T3 $(\mathrm{P}=0.14)$, T4 $(\mathrm{P}=0.16)$, FT4 $(\mathrm{P}=0.81)$ TBG $(\mathrm{P}=0.25)$ or TSH $(\mathrm{P}=0.78)$. Neither was a correlation seen with the lactational exposure. Means and ranges are given in table 2 .

\section{DI-PCBs}

A significant relationship was found between $\mathrm{T} 3$ and dlPCBs $(P=0.047$, see figure 1$)$. No relation was found with T4, FT4, TBG or TSH.

\section{PBDEs}

Congener specific analysis revealed a positive correlation between BDE 99 and T3 ( $\mathrm{P}=0.003$, Figure 2), and with FT4 $(\mathrm{P}=0.048)$. For the $\Sigma \mathrm{PBDEs}$ no significant relationship was seen.

No association was found with T4, TBG or TSH levels.

\section{Discussion}

In the current study a positive relation was seen between dl-PCBs and T3, and a positive relation with T3 and BDE 99 (see Figure 1 and 2). No relationship was seen with TBG.

Table 1 Dioxin, dl-PCB and PBDE exposure

\begin{tabular}{lllll}
\hline & Mean & Range & Standard deviation & 95\% confidence interval \\
\hline Prenatal dioxin (PCDD/F) exposure ITEQ (pg/g lipid in breastmilk), $\mathrm{n}=32$ & 32.6 & $9.05-88.8$ & 64.3 & $25.9-38.5$ \\
\hline Lactational dioxin (PCDD/F) exposure ITEQ (absolute quantity in $\mathrm{ng}), \mathrm{n}=32$ & 66.5 & $4.34-279$ & 64.3 & $43.3-89.6$ \\
\hline Current serum dioxin (PCDD/F) WHO-TEQ (pg/g lipid in serum), $\mathrm{n}=27$ & 2.2 & $0.4-6.1$ & 1.6 & $1.6-2.8$ \\
\hline Current serum dl-PCBs WHO-TEQ (pg/g lipid) & 2.2 & $0.04-7.8$ & 2.0 & $1.4-3.0$ \\
\hline Current serum PBDE (ng/g lipid) $\mathrm{n}=17^{*}$ & 10.5 & $4.9-22.1$ & 4.6 & $8.2-12.9$ \\
\hline
\end{tabular}

Means, ranges, standard deviation and 95\% confidence interval of the exposure to Dioxins, PCBs and PBDE's.

${ }^{*}$ Current serum PBDE levels is calculated with exclusion of the outlier (73.6 ng/g lipids) 
Table 2 Thyroid hormone metabolism parameters

\begin{tabular}{lllll}
\hline Measured objective $n=29$ & Mean & Range & Standard deviation & 95\% confidence interval \\
\hline Free thyroxin (FT4) $\mathrm{pmol} / \mathrm{L}$ & 14.7 & $11.8-20.8$ & 2.5 & $13.7-15.6$ \\
\hline Triiodothyronin (T3) $\mathrm{nmol} / \mathrm{L}$ & 2.6 & $2.1-3.5$ & 0.4 & $2.5-2.7$ \\
\hline Thyroxin (T4) $\mathrm{nmol} / \mathrm{L}$ & 108.6 & $75.0-165.0$ & 22.2 & $100.1-117.1$ \\
\hline Thyroxin-binding globulin (TBG) $\mathrm{mg} / \mathrm{L}$ & 361.4 & $220-650$ & 96.7 & $324.6-398.6$ \\
\hline Thyroid stimulating hormone (TSH) $\mathrm{mU} / \mathrm{L}$ & 1.75 & $0.42-4.5$ & 0.98 & $1.38-2.12$ \\
\hline
\end{tabular}

Thyroid hormone metabolism parameters, means, ranges, standard deviation and $95 \%$ confidence interval.

Reference intervals: FT4: 9-22 pmol/L, T4: 70-140nmol/L, T3: 1.2-3.0 nmol/L, TBG: 7-17 mg/L, TSH: 0.5-5.7 mU/L.

In an earlier study of our cohort an increase in T4 and T4/TBG ratio was seen in children with higher dioxin levels in their breastmilk in the first and eleventh week postpartum [26]. The children now in their adolescence have normal serum TSH and T4 values.

TSH levels were significantly increased in relation to prenatal exposure at eleven weeks postpartum. None of these TSH-levels were above the WHO cut-off point of $5 \mathrm{mU} / \mathrm{L}$, now also proposed to use as a biomarker for dioxin toxicity. However we have found effects on brain development in our cohort at the age of 8-12 years of age, while no baby had a TSH above $5 \mathrm{mU} / \mathrm{L}$ in their postnatal period [30]. Based on these outcomes it would seem a major error for governmental bodies to use a cut-off point of $5 \mathrm{mU} / \mathrm{L}$ as a biomarker for dioxin toxicity.

T3 is a product of the target organs. It looks as if the damage done by the two pollutants dl-PCBs and BDE 99

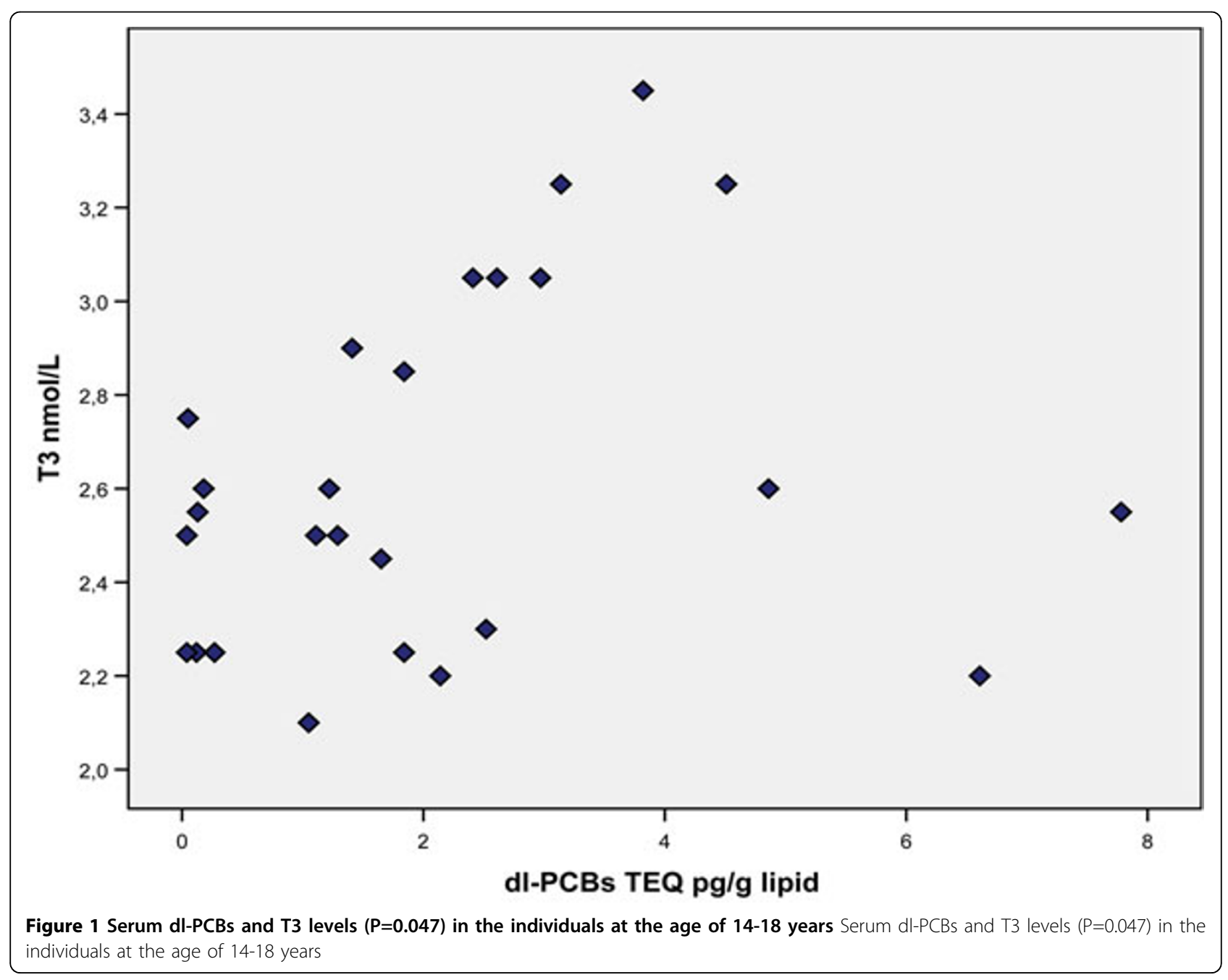




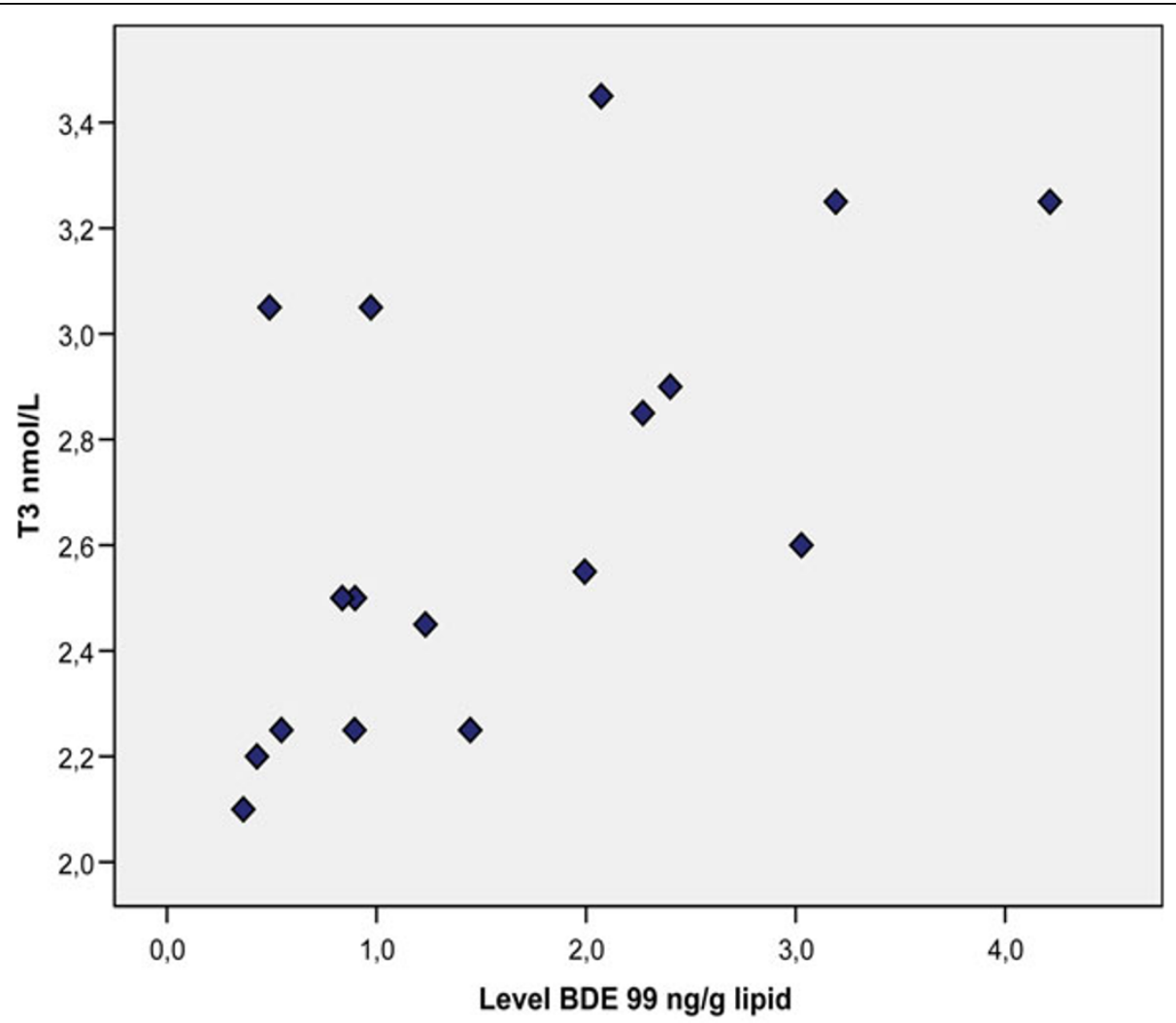

Figure 2 Serum BDE-99 levels and T3 $(P=0.003)$ in the individuals of the cohort at the age of $\mathbf{1 4 - 1 8}$ years. Serum BDE-99 levels and T3 $(P=0.003)$ in the individuals of the cohort at the age of $14-18$ years.

resulting in higher T3 levels takes place in the peripheral target organs perhaps by negatively influencing transporter proteins. It is widely known and accepted that human beings have effective compensation mechanisms. For instance the brain is capable of keeping T3 levels constant over a wide range (30-200 \% of normal) of T4 levels by adapting the different deiodinases. However it is possible that with environmental pollutants transporter proteins are negatively influenced like for example the monocarboxylate transporter 8 (MCT 8), a protein necessary for the transport of T4 and T3 over the membrane into the cell in the hypothalamus, and when this transporter protein is lower or absent severe mental problems can arise as is seen in the Allan-Herndon-Dudley syndrome, a genetic MCT 8 deficiency, that is characterized by severe mental retardation and an increase in T3 but normal T4 and TSH [31]. In other words, a normal functioning pituitary gland and thyroid gland producing enough T4, does not exclude other organs having insufficient hormones due to hormone transporter problems.

Numerous studies have provided evidence that polyhalogenated aromatic hydrocarbons (PHAHs) and their metabolites affect the thyroid hormone system: 1) They may interfere directly with the thyroid gland, 2) with thyroid hormone metabolizing enzymes (uridine- diphosphate-glucuronyl transferases), iodothyronine deiodinases, and sulfotransferases which are located in the liver and the brain, 3) by interfering with the plasma transport system of the thyroid hormone by competing with plasma transthyretin (TTR) binding sites in animals, in humans this TTR is less important and TBG is the main transporter in plasma [32] and 4) influence membrane transporter proteins, that are specific for different target organs [33]. PBDEs have structural similarities to T3 and T4, therefore it has been hypothesized that PBDEs might interfere with the transport and metabolism of T3 and T4 [34]. Another possibility is the upregulation of type 1 deiodinase, which is involved in the deiodination of T4 to T3 and reverse T3 [35].

Doucet [36] published a sharp increase in the content of PBDE's in fetal livers of human fetuses after elective abortions in early to mid-gestation and in the placenta. Total PBDE's increased over time from 284 ng/g lipid in 1998 to $1607 \mathrm{ng} / \mathrm{g}$ lipid in 2006. Main found significant higher PBDE-levels in the breastmilk of mothers whose newborn sons had cryptorchidism [37].

Effects on the thyroid homeostasis in relation to PBDEs have been seen in animal studies. In a study of mink ingesting PBDE via their feed, a decrease in T3 was seen [38]. A decrease in T3 and T4 was also seen in 
fetuses of pregnant sheep who were exposed to BDE-47 [39]. PBDEs have been shown to decrease T4 and free T4 in animals. T3 was also decreased in some studies, but to a lesser extent than total T4 $[40,41]$. Animals don't have TBG like humans for the transport of T4 and $\mathrm{T} 3$ in blood.

In a study on 23 subjects living close to an electronic waste and 26 control, higher TSH levels were found in the studied subjects, who had higher PBDE levels in their serum compared to a control group (382 $\mathrm{ng} / \mathrm{g}$ lipids versus $158 \mathrm{ng} / \mathrm{g}$ lipids) [42]. In a small study investigating 11 electronic dismantling workers, no significant effects were mentioned related to TSH, T3 or T4 [43].

No association of BDE-47 or PCB-153 with TSH or thyroid hormone concentrations were found in 110 men with high consumption of fish from the Baltic Sea [44]. In a later study of 182 females however, a relationship between PCB-153 concentrations in plasma and T3 levels was seen [45].

Thus, besides the remodelling effects of tissues by PBDE's, as described by Main [37] in the form of cryptorchidism during prenatal life, health problems in later life are also possible and we speculate that these health problems are caused by effects on peripheral target organs, maybe through thyroid hormone transporter disruption. The background levels of the PBDE's are rather high in the Netherlands compared to other European countries but still ten times lower than in the US. An enhanced effect due to multiple exposures to dl-PCBs as well might additively worsen the situation.

In conclusion, the thyroid hormone system in Dutch adolescents is influenced by current levels of dl-PCBs and PBDEs. Most plausible is a toxic effect in the peripheral target organs, involving the membrane transporter proteins. A disruption may be compensated, but it is questionable if this compensation is sufficient for all organs depending on thyroid hormones. Pathology in some target organs may be present. Quantification of this compensation is currently very difficult.

\section{Author's contributions}

ML, GtT, TV, WvA, TvT and JK were equally involved in the set-up and execution of the epidemiological part of the study, while ML and GtT should be considered as first authors. ML, KO and PdV were all involved in the study and performed the measurements of the chemicals. $\mathrm{AB}, \mathrm{MKvK}, \mathrm{CM}, \mathrm{HR}$ and $\mathrm{GC}$ were involved in preparing the paper.

\section{Abbreviations}

I-TEQ: International Toxic Equivalency factor; PCB: polychlorinated biphenyls; PCDD: polychlorinated dibenzo-p-dioxins; PCDF: furans = polychlorinated dibenzo-furans; PBDE: polybrominated diphenylether; HBCD: hexabromocyclododecane; TBBPA: tetrabromobisphenol A; DBDE: decabromodiphenyl ether; FT4: Free thyroxine; T3: triiodothyronine; T4: thyroxine; TBG: thyroxine-binding globulin; TSH: thyroid stimulating hormone; PCB: polychlorinated biphenyls; BDE 99: brominated diphenyl ether; MCT 8: monocarboxylate transporter 8

\section{Acknowledgements}

The work has been funded by the EU FP6 coordination action HENVINET, contract no 037019.

The authors wish to thank the participants of the study, and their parents, for their cooperation; Dr. J. Oosting for his help with the statistics; and P. Serné, F. vd Wielen and J. Parsons of the laboratory of the Institute for Biodiversity and Ecosystem Dynamics for their help with the chemical measurements. We are indebted to Dr. Matthijs Westra paediatrician for his help to investigate the children in the Zaans Medical Centre "De Heel" Zaandam.

Thanks also to Scott Randall who did the language review. The study was also supported by E.C. grant: OBELIX : 227391 This article has been published as part of Environmental Health Volume 11 Supplement 1, 2012: Approaching complexities in health and environment. The full contents of the supplement are available online at http://www. ehjournal.net/supplements/11/S1.

\section{Author details}

'Department of Paediatrics and Neonatology, Emma Children's Hospital Academic Medical Centre, Amsterdam, The Netherlands. ${ }^{2}$ IBED/ESS, University of Amsterdam, Amsterdam, The Netherlands. ${ }^{3}$ University Hospital Aachen RWTH, Department of Dermatology, Pauwelstrasse 30, 52074 Aachen, Germany. ${ }^{4}$ Department of Paediatrics and Neonatology, Westfriesgasthuis, Maelsonstraat 3, 1624 NP Hoorn, The Netherlands. ${ }^{5}$ KWR Watercycle Research, POBox 1072, 3430 BB Nieuwegein, The Netherlands. ${ }^{6}$ Ministry of Housing, Spatial Planning and the Environment, The Hague, The Netherlands. ${ }^{7} \mathrm{NILU}$ - Norwegian Institute for Air Research, Kjeller, Norway. ${ }^{8}$ WHO, Regional Office for Europe,Copenhyen, Scherfigsvej 8, Denmark. ${ }^{9}$ Institute of Food Bioresources (IBA), Bucharest, Romania. ${ }^{10}$ National Institute of Public Health, Cernavaca, Morelos, Mexico. ${ }^{11}$ Istituto Superiore di Sanita, Rome, Italy. ${ }^{12}$ Ecobaby Foundation, Hollandstraat 6, 3634 AT Loenersloot, The Netherlands.

\section{Competing interests}

The authors declare that they have no competing interests.

Published: 28 June 2012

\section{References}

1. Olie K, Vermeulen PL, Hutzinger O: Chlorodibenzo-p-dioxins and chlorodibenzofurans are trace components of fly and flue gas of some municipal incinerators in The Netherlands. Chemosphere 1977, 6:455-459.

2. World Health Organisation: PCDD and PCDF emissions from incinetators for minicipal sewage sludge and solid waste - Evaluation of human exposure,. WHO Environ. Health edn Copenhagen: WHO; 1987.

3. Rappe C: Analysis of polychlorinated dioxins and furans. Environ SCi Technol 1984, 18:78A.

4. De Voogt P, Brinkman UAT: Production, properties and usage of polychlorinated biphenyls. In Halogenated biphenyls, terphenyls, naphtalenes, dibenzodioxins and related products.. Second edition. Amsterdam: Elsevier;Kimbrough RD, Jensen AA 1989:3-45.

5. Gomara B, Herrero L, Ramos JJ, Mateo JR, Fernandez MA, Garcia JF, González MJ: Distribution of polybrominated diphenyl ethers in human umbilical cord serum, paternal serum, maternal serum, placentas, and breast milk from Madrid population, Spain. Environ Sci Technol 2007, 41:6961-6968.

6. Leijs MM, van Teunenbroek T, Olie K, Koppe JG, ten Tusscher GW, van Aalderen WM, de Voogt P: Assessment of current serum levels of PCDD/ $\mathrm{Fs}$, dl-PCBs and PBDEs in a Dutch cohort with known perinatal PCDD/F exposure. Chemosphere 2008, 73:176-181.

7. Cariou R, Antignac J-P, Zalko D, Berrebi A, Cravedi J-P, Maume D, Marchand P, Monteau F, Riu A, Andre F, Le Bizec B: Exposure assessment of French women and their newborns to tetrabromobisphenol-A: Occurrence measurements in maternal adipose tissue, serum, breast milk and cord serum. Chemosphere 2008, 73:1036-1041. 
8. Lilienthal H, van der Ven LTM, Roth-Haerer A HAPA, Vos JG Neurobehavioral toxicity of brominated flame retardants:differential effects of PBDE-99, TBBP-A and HBCD and endocrine relation. Organohalogen Compounds 2006, 68:128-130.

9. Van der Ven LTM, van de Kuil A, Verhoef A, Verwer CM, Lilienthal $H$, Leonards $P$, et al: Endocrine effects of tetrabromobisphenol-A (TBBP-A) in Wistar rats as tested in a one-generation reporduction study and a subacute toxicity study. Toxicology 2008.

10. Khan MA, Hansen LG: Ortho-substituted polychlorinated biphenyl (PCB) congeners (95 or 101) decrease pituitary response to thyrotropin releasing hormone. Toxicol Lett 2003, 144:173-182.

11. Haddow JE, PAlomaki GE, Allan WC, Williams JR, Knight GJ, Gagnon J, O'Heir CE, Mitchell ML, Hermos RJ, Waisbren SE, Faix JD, Klein RZ: Maternal thyroid deficiency during pregnancy and subsequent neuropsychological development of the child. New England Journal of Medicine 1999, 341:549-602.

12. Baars AJ, Bakker Ml, Baumann RA, Boon PE, Freijer Jl, Hoogenboom LA, Hoogerbrugge R, van Klaveren JD, Liem AK, Tragg WA, de Vries J: Dioxins, dioxin-like PCBs and non-dioxin-like PCBs in foodstuffs: occurrence and dietary intake in The Netherlands. Toxicol Lett 2004, 151:51-61.

13. Pirkle JL, Wolfe WH, Patterson DG, Needham LL, Michalek JE, Miner JC, Peterson MR, Phillips DL: Estimates of the half-life of 2,3,7,8tetrachlorodibenzo-p-dioxin in Vietnam Veterans of Operation Ranch Hand. J Toxicol Environ Health 1989, 27:165-171.

14. Lundqvist C, Zuurbier M, Leijs MM, Johansson C, Ceccatelli S, Saunders M, Schoeters G, ten Tusscher G, Koppe JG: The effects of PCBs and dioxins on child health. Acta Paediatrica 2006, 95(453):55-64.

15. Zetterstrom R: Child health and environmental pollution in the Aral Sea region in Kazakhstan. Acta Paediatr Suppl 1999, 88:49-54

16. Goldman LR: Chemicals and children's environment: what we don't know about risks. Environ Health Perspect 1998, 106(Suppl 3):875-880.

17. ten Tusscher GW, de Weerdt J, Roos CM, Griffioen RW, De Jongh FH, Westra M, van der Slikke JW, Oosting J, Koppe JG: Decreased lung function associated with perinatal exposure to Dutch background levels of dioxins. Acta Paediatr 2001, 90:1292-1298.

18. Rogan WJ, Gladen BC, Hung KL, Koong SL, Shih LY, Taylor JS, Wu YC, Yang D, Ragan NB, Hsu CC: Congenital poisoning by polychlorinated biphenyls and their contaminants in Taiwan. Science 1988, 241:334-336.

19. Pluim HJ, Koppe JG, Olie K, van der Slikke JW, Slot PC, van Boxtel CJ: Clinical laboratory manifestations of exposure to background levels of dioxins in the perinatal period. Acta Paediatr 1994, 83:583-587.

20. Weisglas-Kuperus N, Sas TC, Koopman-Esseboom C, van der Zwan CW, De Ridder MA, Beishuizen A, Hooijkaas H, Suaer PJ: Immunologic effects of background prenatal and postnatal exposure to dioxins and polychlorinated biphenyls in Dutch infants. Pediatr Res 1995, 38:404-410,

21. Ten Tusscher GW, Steerenberg PA, van Loveren H, Vos JG, dem Borne AE, Westra M, van der Slikke JW, Olie K, Pluim HJ, Koppe JG: Persistent hematologic and immunologic disturbances in 8-year-old Dutch children associated with perinatal dioxin exposure. Environ Health Perspect 2003, 111:1519-1523.

22. Ten Tusscher GW: Later childhood effects of perinatal exposure to background levels of dioxins in The Netherlands. PhD thesis University of Amsterdam; 2002.

23. Jacobson $\mathrm{JL}$, Jacobson SW, Humphrey HE: Effects of exposure to PCBs and related compounds on growth and activity in children. Neurotoxicol Teratol 1990, 12:319-326.

24. Lanting Cl, Patandin S, Fidler V, Weisglas-Kuperus N, Sauer PJ, Boersma ER, Touwen BC: Neurological condition in 42-month-old children in relation to pre- and postnatal exposure to polychlorinated biphenyls and dioxins. Early Hum Dev 1998, 50:283-292.

25. Gladen BC, Rogan WJ, Hardy P, Thullen J, Tingelstad J, Tully M: Development after exposure to polychlorinated biphenyls and dichlorodiphenyl dichloroethene transplacentally and through human milk. J Pediatr 1988, 113:991-995

26. Pluim HJ, Koppe JG, Olie K, Vd Slikke JW, Kok JH, Vulsma T, van Tijn D, de Vijlder JJM: Effects of dioxins on thyroid function in newborn babies. Lancet 1992, 339:1303.

27. Pluim HJ: Dioxins: pre- and postnatal exposure in the human newborn. PhD thesis University of Amsterdam; 1993.

28. Ilsen A, Briet JM, Koppe JG, Pluim HJ, Oosting J: Signs of enhanced neuromotor maturation in children due to perinatal load with background levels of dioxins. Follow-up until age 2 years and 7 months. Chemosphere 1996, 33:1317-1326.

29. Pluim HJ, Koppe JG, Olie K, van der Slikke JW, Slot PC, van Boxtel CJ: Clinical laboratory manifestations of exposure to background levels of dioxins in the perinatal period. Acta Paediatr 1994, 83:583-587.

30. TenTusscher GW: Neurodevelopmental influences of perinatal dioxin exposure as assessed with magnetoencephalography, electroencephalography,psychological and neuromotor tests. University of Amsterdam; 2002

31. Friesema ECH, Grueters A, Biebermann $H$, Krude $H$, von Moers A, Kester Kuiper GG, Balkassmi S, Uitterlinden AG, Koehrle J, Rodien P, Halestrap AP, Visser TJ: Association between mutations in a thyroid hormone transporter and severe X-linked psychomotor retardation. Lancet 2004, 364:1435-1437.

32. Brouwer A, Morse DC, Lans MC, Schuur AG, Murk AJ, Klasson-Wehler E, Bergman A, Visser TJ: Interactions of persistent environmental organohalogens with the thyroid hormone system: mechanisms and possible consequences for animal and human health. Toxicol Ind Health 1998, 14:59-84.

33. Richardson VM, Staskal DF, Diliberto JJ, deVito MJ, Birnbaum LS: Effects of 2,2 $4,4^{\prime}$-tetrabromodiphenyl ether on nuclear receptor regulated genes: implications for thyroid hormone disruption. Organohalogen Compounds 2006, 68:403-406.

34. Birnbaum LS, Staskal DF: Brominated flame retardants: cause for concern? Environ Health Perspect 2004, 112:9-17.

35. Stapleton HM, Kelly SM, Pei R, Letcher RJ, Gunsch C: Metabolism of polybrominated diphenylethers (PBDEs) by human hepatocytes in vitro. Environ Health Perspect 2009, 117:197-202.

36. Doucet J, Tague B, Arnold DL, Cooke GM, Hayward S, Goodyer CG: Persistent organic Pollutants Residues in Human Fetal Liver and Placenta from Greater Montreal, Quebec:A longitudinal Study from 1998-20. Environ Health Perspect 2008, 116:637-643.

37. Main KM, Kiviranta $H$, Virtanen HE, Sundquist E, Tuomisto JT, Tuomisto J, Vartiainen T, Skakkebæk NE, Toppari J: Flame Retardants in Placenta and Breastmilk and Cryptorchidism in Newborn Boys. Environ Health Perspect 2007, 115:1519-1526.

38. Zhang S, Bursian SJ, Martin PA, Chan HM, Tomy G, Palace VP, Mayne GJ, Martin JW: Reproductive and developmental toxicity of a pentabrominated diphenyl ether mixture, $\mathrm{DE}-71(\mathrm{R})$, to ranch mink (Mustela vison) and hazard assessment for wild mink in the Great Lakes region. Toxicol Sci 2009, 110:107-116.

39. Abdelouahab N, Suvorov A, Pasquier JC, Langlois MF, Praud JP, Takser L: Thyroid Disruption by Low-Dose BDE-47 in Prenatally Exposed Lambs. Neonatology 2009, 96:120-124.

40. van der Ven LTM, van de Kuil A, Verhoef A, Fernandez-Canton R, Germer S, Lilienthal $H$, et al: Endocrine disrupting effects of selected brominated flame retardants in rats. Organohalogen Compounds 2006, 68:988-991.

41. Zhou T, Ross DG, DeVito MJ, Crofton KM: Effects of short-term in vivo exposure to polybrominated dipehnyl ethers on thyroid hormones and hepatic enzyme activities in weanling rats. Toxicological Sciences 2001, 61:76-82.

42. Yuan J, Chen L, Chen D, Guo H, Bi X, Ju Y, Jiang P, Shi J, Yu Z, Yang J, Li L, Jiang Q, Sheng G, Fu J, Wu T, Chen X: Elevated serum polybrominated diphenyl ethers and thyroid-stimulating hormone associated with lymphocytic micronuclei in Chinese workers from an E-waste dismantling site. Environ Sci Technol 2008, 42:2195-2200.

43. Julander A, Karlsson M, Hagstrom K, Ohlson CG, Engwall M, Bryngelsson IL, Westberg $\mathrm{H}$, van Bavel B: Polybrominated diphenyl ethers-plasma levels and thyroid status of workers at an electronic recycling facility. Int Arch Occup Environ Health 2005, 78:584-592.

44. Hagmar L, Bjork J, Sjodin A, Bergman A, Erfurth EM: Plasma levels of persistent organohalogens and hormone levels in adult male humans. Arch Environ Health 2001, 56:138-143.

45. Hagmar L, Rylander L, Dyremark E, Klasson-Wehler E, Erfurth EM: Plasma concentrations of persistent organochlorines in relation to thyrotropin and thyroid hormone levels in women. Int Arch Occup Environ Health 2001, 74:184-188.

doi:10.1186/1476-069X-11-S1-S10

Cite this article as: Leijs et al:: Thyroid hormone metabolism and environmental chemical exposure. Environmental Health 2012 11(Suppl 1): S10. 